論

\title{
平面ディスプレイの人間工学的要件
}

\author{
正会員泾田悟

\section{Human Factors Requirements for Flat Panel Displays} \\ Satoru Kubota (Member) \\ Faculty of Engineering, Seikei University
}

\begin{abstract}
This paper is concerned with the important visual variables that determine legibility of computer-controlled flat panel displays (FPDs). Thirty - five FPDs (29 LCDs, 3 PDPs, 2 ELDs, and 1 VFD) and five CRTs are analysed in relation to the following photometric properties: (1) Luminance and contrast ratio. (2) Specular reflectance. (3) Viewing angle dependency of contrast. Special equipments are developed and standardized conditions are applied to the measurements. For each visual variable the recommended level is determined on the basis of subjective evaluations and is compared with the presently used levels for that variable on several different displays. It can be concluded that manufacturers should pay more attention to human factors when designing displays.
\end{abstract}

\section{1.はじめに}

近年，軽量・薄型の平面ディスプレイ(Flat Panel Display: F P D)が, コンピュータの表示装置として広く使われるようになっ た、コンピュータの表示装置として使われているF P Dには，液 晶ディスプレイ (Liquid Crystal Display:L C D)をはじめ, プラ ズマディスプレイ(Plasma Display Panel: P D P), エレクトロル ミネッセントディスプレイ(Electroluminesent Display: E L D), 蛍光表示管 (Vacuum Fluorescent Display:V F D)などがあ る.

このような F P Dの人間工学的な側面, すなわち, 表示特性と 視認性や視覚負担との関係については，ほとんど検討されていな い. C R Tディスプレイについては，視認性や視覚負担という側 面から，具備すべき物理的条件がある程度明らかにされてきた。 しかし，FPDについては，従来のCRTディスプレイを对象と した設計指針1),2)が必ずしも適用できるわけではない.たと之ば, 非発光型として特徵づけられる L C D の輝度特性と視認性の関係 については，自発光型のC R Tディスプレイによる実験結果が必 ずしも利用できない．また， L C D の特徵であるコントラストの 観視角依存性についても，視覚系に即した測定・評価の方法が求 められている。ささらに，各種 F P Dの表示特性とオフィスの照明 環境要因の関係についてもほとんど明らかにされていない. そこで, 本研究では, L C Dを中心とする各種 F P D を対象と

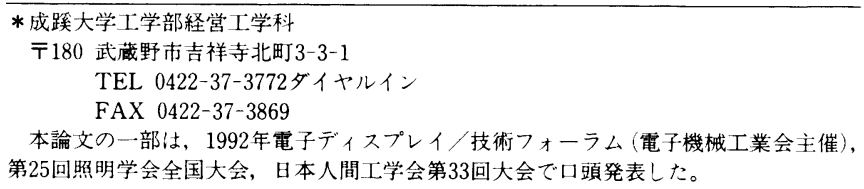

して，どのような物理的条件を具備すれば，実際のオフィスの照 明環境下で, ユーザにとって見やすい表示が得られるかについて， 実験的に検討することを目的とする。

本研究は，表示特性の測定と見やすさに関する主観評価実験か ら構成される。まず，35機種の F P D ( LCD-29, PDP-3,ELD$2, \mathrm{VFD}-1)$ と比較対照のための 5 機種の C R Tディスプレイ計 40 機種のディスプレイについて，表示文字の視認性に関連した次の ような表示特性を測定した。すなわち，(1)輝度およびコントラス ト，（2）鏡面反射率，（3）コントラストの観視角依存性である。測 定にあたっては，ディスプレイを使用するオフィスの照明環境要 因を考慮できるようにした。次に，これらのディスプレイのうち 22 機種について, 表示文字の見やすさに関する多次元の評価項目 による主観評価実験を行った。その上で, 物理的な測定結果と工 一ザの主観評価結果を対応づけ，見やすいF P Dの物理的条件に ついて検討した。これらの結果は, ユーザの視覚特性とオフィス の照明環境要因を考慮したF P Dの設計指針を設定する際の基礎 資料となり得る。

\section{2. 表示特性の測定}

\section{1 測定・評価の対象機種}

表 1 に測定・評価の対象とした40機種のディスプレイの動作モ ード，画素数などの一覧を示した。これらのディスプレイには， ごく一部ではあるが，試作機や実験用に特注されたものも含まれ ており，必ずしも市場に出荷されているものだけではない．また， ほとんどの機種は1988年以降に出荷を開始したもので，約半数は 1990年以降に出荷を開始した製品である.なお,これらの機種は, 日本電子工業振興協会V D T 動向調査専門委員会を通じて, 各メ 一カから提供されたものである。 
表中の*を付記した機種は，後半で述べる主観評価実験に使用 した機種を示す。

\section{2 輝度およびコントラスト}

\section{2 .1 測定方法}

C R Tディスプレイについては, JIS X-60413)で輝度やコント ラストの測定方法が規定されているが，F P Dについては，標準 的な方法は定められていない. 本研究では, JIS X-6041と日本電 子工業振興協会のV D T ガイドラインに関する調査研究報告書 ${ }^{2}$ を参考にして，作業場の照明環境を考虑した評価が可能となる測 定方法を採用した。

C R T ディスプレイの場合, 輝度抢よびコントラストに影響を 及ぼす照明環境要因としては，スクリーンの鉛直面照度を測定す ればよかった。つまり，スクリーンがC R Tディスプレイのよう に均等拡散反射面とみなせる場合は, 外光拡散反射輝度 $(\mathrm{Ld})$ は, スクリーンの鉛直面照度 $(\mathrm{Ei})$ と表示面拡散反射率 $(\rho)$ によって,

表 1 測定・評価の対象となった機種 （は主観評価実験に使った機種を示す）

\begin{tabular}{|c|c|c|c|c|}
\hline 機種番号 & 種別 & 動作七ート・・ベタクラ仆等 & 画素数 & 画素比 ^f(mm) \\
\hline$* 1$ & L C D & STN任- 反射型 & $640 \times 400$ & 0.36 \\
\hline$* 2$ & & STN任- 反射型 & $640 \times 400$ & 0.31 \\
\hline 3 & & STN任- 反射型 & $640 \times 400$ & 0.31 \\
\hline 4 & & STN仜D- 反射型 & $640 \times 400$ & 0.25 \\
\hline$* 5$ & & TFT白黒 反射型 & $640 \times 400$ & 0.33 \\
\hline 6 & & TFT白黒 反射型 & $640 \times 400$ & 0.33 \\
\hline$* 7$ & & STN7 $7^{-}$冷陰極管 & $640 \times 400$ & 0.30 \\
\hline$* 8$ & & 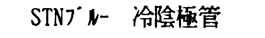 & $640 \times 400$ & 0.36 \\
\hline$* 9$ & & STN7 $\boldsymbol{n}$ - 冷陰極管 & $640 \times 400$ & 0.30 \\
\hline$* 10$ & & STN白黒 冷陰極管 & $640 \times 400$ & 0.33 \\
\hline$* 11$ & & STN白黒 冷陰極管 & $640 \times 400$ & 0.31 \\
\hline$* 12$ & & STN白黒 冷陰極管 & $640 \times 400$ & 0.33 \\
\hline$* 13$ & & STN白黒 冷陰極管 & $640 \times 400$ & 0.33 \\
\hline$* 14$ & & STN白黒 冷陰極管 & $640 \times 400$ & 0.275 \\
\hline$* 15$ & & STN白黒 冷陰極管 & $640 \times 400$ & $0.36 \times 0.41$ \\
\hline$* 16$ & & STN白黒 冷陰極管 & $640 \times 400$ & 0.36 \\
\hline$* 17$ & & STN白黒 冷陰極管 & $640 \times 400$ & 0.36 \\
\hline 18 & & STN白黒 冷陰極管 & $640 \times 400$ & 0.325 \\
\hline 19 & & STN白黒 冷陰極管 & $640 \times 400$ & 0.275 \\
\hline 20 & & STN白黒 冷陰極管 & $640 \times 400$ & 0.325 \\
\hline 21 & & STN白黒 冷陰極管 & $640 \times 400$ & 0.30 \\
\hline 22 & & STN白黒 冷陰極管 & $640 \times 480$ & 0.33 \\
\hline 23 & & STN白黒 冷陰極管 & $738 \times 525$ & 0.285 \\
\hline$* 24$ & & TFD白黒 冷陰極管 & $1152 \times 900$ & 0.21 \\
\hline 25 & & TFT白黒 冷陰極管 & $640 \times 400$ & 0.325 \\
\hline 26 & & DSTN力ラ- 冷陰極管 & $640 \times 400$ & 0.33 \\
\hline$* 27$ & & TFT力ラ－冷旡極管 & $640 \times 400$ & 0.312 \\
\hline 28 & & TFT力j- 冷陰極管 & $640 \times 400$ & 0.33 \\
\hline 29 & & TFT力ラ-＼cjkstart冷陰極管 & $640 \times 400$ & 0.30 \\
\hline$* 30$ & P D P & DC型PDP & $640 \times 400$ & $0.30 \times 0.36$ \\
\hline 31 & & DC型PDP & $640 \times 400$ & 0.30 \\
\hline$* 32$ & & DC型PDP & $640 \times 400$ & 0.33 \\
\hline $\begin{array}{r}* 33 \\
34\end{array}$ & E L D & $\begin{array}{l}\text { 薄膜型EL } \\
\text { 蓒膜型EL }\end{array}$ & $640 \times 480$ & 0.30 \\
\hline$* 35$ & VF D & 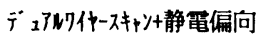 & $640 \times 400$ & 0.28 \\
\hline 36 & C R T & 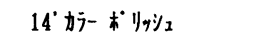 & $640 \times 400$ & 0.31 \\
\hline$* 37$ & & $14^{\circ}$ 千/吅 拡散処理 & $640 \times 475$ & 0.33 \\
\hline$* 38$ & & 15’モ/吅 マNチコート & $1066 \times 725$ & 0.25 \\
\hline 39 & & 14’力う一拡散処理 & $1120 \times 750$ & 0.21 \\
\hline 40 & & $14^{\circ}$ カラ- 拡散処理 & $1120 \times 750$ & 0.26 \\
\hline
\end{tabular}

LCD:Liquid crystal display, PDP:Plasma display panel, ELD:Electroluminesent display, VFD:Vacuum fluorescent display, STN:Super-twisted nematic, TFT:Thin-film transistor, DSTN:Double-layerd STN, TFD:Thin-film diode
次のように示すことができた。

$$
\mathrm{Ld}=\frac{\mathrm{Ei} \cdot \rho}{\pi}
$$

しかし，CRTディスプレイ以外は，スクリーンを均等拡散反射 面とみなすことができない。

均等拡散反射面でないスクリーンの反射特性を評価する方法と しては, 次のような 3 つ測定方法が考えられる。（1) 積分球を使 って，あらゆる方向からの入射光に対する反射光を積分したかた ちで測定する. (2)平行光束を使って, あらゆる方向からの入射光 に対する反射率を測定する。(3) 標準的な照明環境条件下で拡散反 射輝度を測定し，拡散反射係数を求める。

これらの方法のうち，(1)は，鏡面反射成分と拡散反射成分を分 離できないこと，また，実際のオフィス環境下での輝度特性を予 測できないという難点があり実際的ではない.(2)は, 実際のオフ イスでスクリーンの鉛直面にあらゆる方向からどのような強さの 入射があるかというデータが存在すれば, 実際のオフィスでの輝 度特性を算出できる。ただし，オフィスに打竟視野の輝度分布 のデー夕はあっても，鉛直面に対する入射光の分布デー夕は存在 しない.（3）は, 照明環境条件の設定の仕方によって, 測定值に差 が生じる。しかし，3つの方法の中では, 実際のオフィスの照明 環境下でのスクリーンの輝度特性を評価するための, 最も現実的 な方法であるといえる。

そこで，本研究では，標準的なオフィス環境を設定し，スクリ 一ンの鉛直面照度が $120,300,750 \mathrm{~lx}$ の条件でスクリーンの明部と 暗部の輝度を測定した。ここで，標準的なオフィスとは，図 1 に 示したように，壁面の反射率 $60 \%$, 床面の反射率 $20 \%$ の無空実験 室である。照明は，40W3波長域型の白色蛍光灯 2 灯の照明器具 12 台を用いた。これらの照明器具は, 水平面照度 $0 \sim 1,500 \mathrm{~lx}$ の範囲 で調光できるようになっており，ルーバは付いていない。また， 壁面の反射率 $60 \%$, 床面の反射率 $20 \%$ は，オフィスの平均的な值 として設定したものである。スクリーンの鉛直面照度は, 天井の 調光式の蛍光灯を制御することによって変化させた。スクリーン の鉛直面照度 $120,300,750 \mathrm{~lx}$ は，VDT作業場の照明環境の実態 調查結果 ${ }^{4}$ より，お抢むね 5 , 50,95 パーセンタイル值に対応させた ものである。

輝度は, 垂直に立てたスクリーンの中央を法線方向 $50 \mathrm{~cm}$ から 測定した。スクリーンの中央に $5 \mathrm{~cm} \times 5 \mathrm{~cm}$ の全画素オンまたはオ フのパターンを表示して測定した。輝度計は, TOPCON BM-3 を使用した。測定角は $2^{\circ}$ である。測定にあたっては, 高輝度の対 象物が映り込まないように配慮した。したがって, 測定值には, 鏡面反射の輝度は含まれていない. なお, 輝度とコントラストが 調節できる機種については, 最大輝度, 最大コントラストで測定 した。 CRTディスプレイについては，測定者の主観により，ス

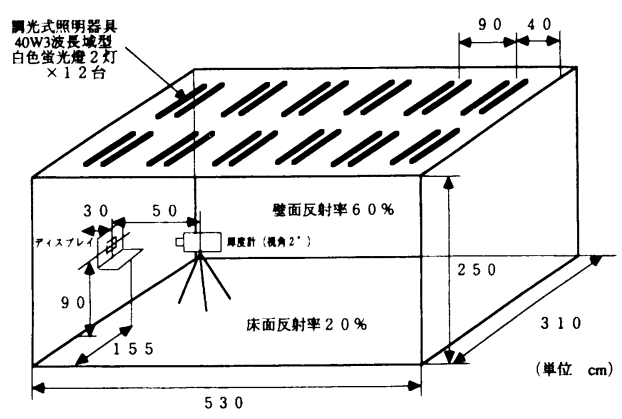

図 1 表示特性の測定を行った実験室 
クリーン鉛直面照度 $120 \mathrm{~lx}$ で文字の形態がくずれない最大発光輝 度に調節した。この測定結果から, コントラスト比を算出した。

\section{2 .2 測定結果}

図 2 にスクリーン鉛直面照度 $120,300,7501 \mathrm{x}$ における輝度とコ ントラストの測定結果を示した。困中の番号は機種を示し，3つ の点を結ぶ線の長さは，スクリーン鉛直面照度の影響の大きさを 示す.すなわち, この線が長い機種ほど, 表示面の拡散反射係数 が大きいことを示している。

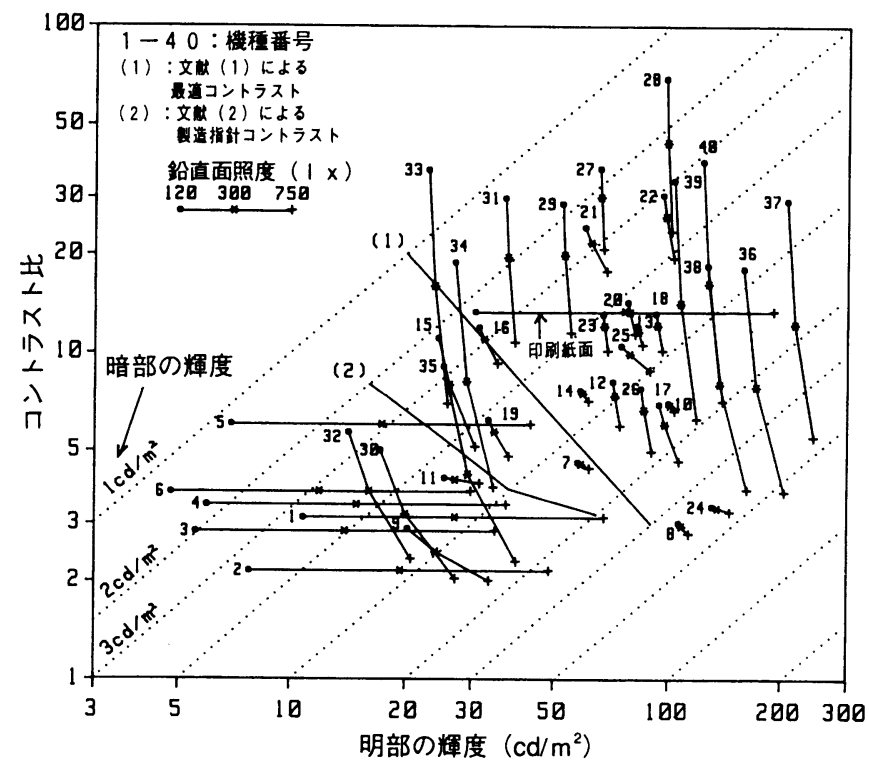

図2 スクリーン鉛直面照度 $120,300,750 \mathrm{~lx}$ における 各ディスプレイの輝度およU゙コントラスト比

困中の線 (1)は, 罋田 ${ }^{1)}$ が示したC R Tディスプレイの最適コン トラストレベルで, 線 (2) は, 日本電子工業振興協会のVDTがイ ドライン 2)によって示された C R Tディスプレイの製造指針コン トラストレベルである。また，比較のために，拡散反射率 $80 \%$ の 紙に印刷されたコントラスト比13の一般的な印刷紙面を図中に示 した．この図から，ディスプレイの輝度とコントラストに関する 相対的な評価ができる。

機種番号36４0は，C R Tディスプレイである。いずれもスク リーン鉛直面照度の上昇によって，コントラストが大きく低下す ることがわかる。これは，C R Tディスプレイの表示面拡散反射 係数が比較的大きいためである。ただし, 発光輝度が十分出せる ために, 最適コントラストを示した直線 (1)を大きく上回ってい る.

機種番号7〜29は, 冷陰極管をバックライトにした L C D であ る、スクリーンの鉛直面照度によるコントラストの変化は, C R Tディスプレイと比較して小さい。 これは, バックライト型 L C Dの表示面拡散反射係数が C R Tディスプレイと比較して一桁小 さいためである。また，バックライト型 L C D は，一部の機種を 除いて，(1)の線を上回っていることがわかる.

機種番号 1 ～6は，反射型 L C Dである。 反射型 L C D は，スク リーンの鉛直面照度に対して, コントラスト比は一定で, 輝度が 変化する，反射型L C D は，スクリーン鉛直面照度が750 lx あっ ても, 輝度とコントラストが足りない。このうち，5と6は T F T の反射型である。これらは, 暗部の輝度が低いため, 他の反射型 L C D よりコントラストは高いが, 輝度が不足である。一般的な
オフィスでは, 十分な輝度を確保するために, 補助照明を利用す る必要があろう。反射型 L C D については，図中の印刷紙面と対 比することによって性能が理解できよう。

その他, P D P (30〜32), E L D (33,34), V F D (35)は, ほと んどが $30 \mathrm{~cd} / \mathrm{m}^{2}$ 程度の輝度しか出せないために，スクリーン鉛直 面照度をかなり制限しても十分な輝度とコントラストが確保でき ないものが多いことがわかる。

\section{3 鏡面反射率}

\subsection{1 測定方法}

拡散処理が施された表示面の鏡面反射率は, 映り込む光源の大 きさに依存する。そこで，次のような条件で，鏡面反射輝度を測 定し鏡面反射率を求奴。光源の入射角 $7.5^{\circ}$; ディスプレイから 光源㧍よび輝度計までの距離 $50 \mathrm{~cm}$; 光源は, 輝度が一様な円形 で，大きさはディスプレイから見た視角で， $1,3,5,7,10^{\circ} \phi$ の 5 条件; 光源の輝度は, 約 $10,000 \mathrm{~cd} / \mathrm{m}^{2}$, ただし光源の大きさ $10^{\circ} の$ 条件では約 $5,000 \mathrm{~cd} / \mathrm{m}^{2}$; 輝度計の測定角は光源の大きさ $1^{\circ}$ 一 $5^{\circ}$ の条件で $0.2^{\circ}, 7^{\circ} \sim 10^{\circ}$ の条件で $2^{\circ}$ とした. なお, 光源は, 輝度が均一なボール型の白色蛍光灯を用い, 光源径は光源の直前 に配置したアパーチャーを差し替えることによって変えた。

\subsection{2 測定結果}

図 3 に, 各ディスプレイの鏡面反射率を, 映り込み光源の大き さとの関係で示した，比較のために，屈折率1.5の一般的ながラス 表面の反射率を四中に示した。

最も鏡面反射率が低かったのは，機種番号38のマルチコーティ ングが施された C R Tディスプレイである。次いで，機種番号 37,39,40で，いずれも拡散処理が施されたC R Tディスプレイで ある. L C D は，反射防止処理をしていない自発光型のディスプ レイ $(31,35,36)$ より鏡面反射率が高いものが多い。特に, 最新 のT F TのカラーL C D (27～29) は鏡面反射率が高い。これは, カラーフィルタの鏡面反射率が高いためである。カラーフィルタ は, 光学密度を高めるためにC $\mathrm{r}$ を使うことが多く, これが鏡面

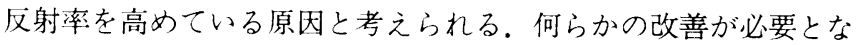
ろう。

L C D は, 陽画表示で使用する場合が多いので, 陰画表示中心 のCRTディスプレイよりは有利ではある11),. しかし，測定した

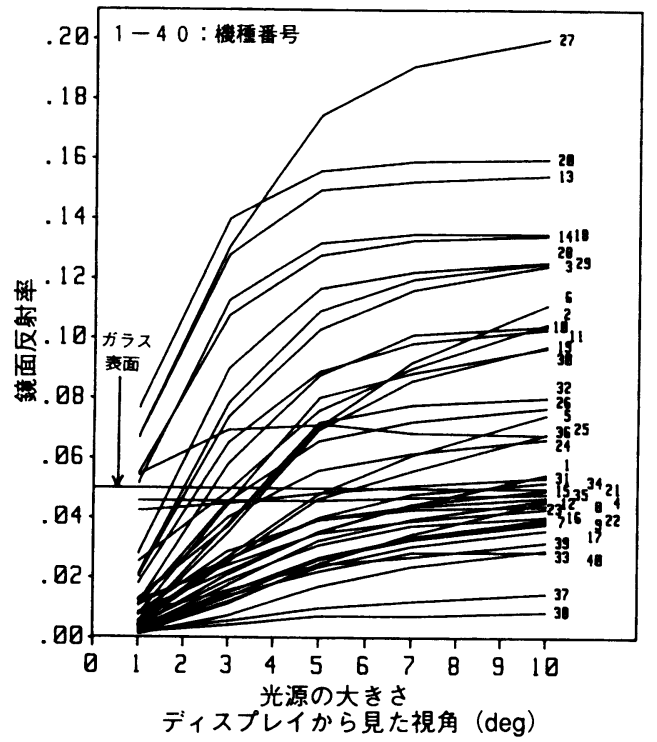

図3映り込み光源の大きさと鏡面反射率の関係 


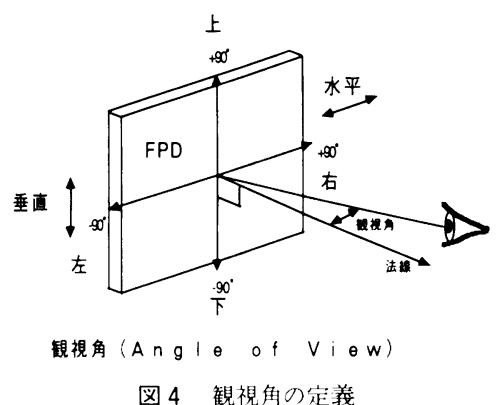

L C Dの約 $1 / 3$ は， $10^{\circ}$ の大きさの光源に対方る鏡面反射率が 0.1 以上ある。鏡面反射率 0.1 という值は, ガラスの表面の鏡面反射率 が0.05程度であるから，その約 2 倍である。C R Tディスプレイ では, いわゆるポリッシュのディスプレイは，一般のオフィスで は使うべきではないとされている6. $\mathrm{L}$ C D についても，できる限 り鏡面反射率を下げるべきである。

ただし，映り込みの立ちやすさは，鏡面反射率だけではなく， ディスプレイの表示輝度にも依存する。 そこで, 表示輝度の要因 も考慮して，映り込みができるだけ目立たない物理的条件を明ら かにする必要がある。この点については, 主観評価実験の項で検 討古る。

\section{4 コントラストの観視角依存性}

\section{4 .1 測定方法}

筆者は，図 4 に示したように, スクリーンの法線に対する角度 を観視角と定義し，水平方向 $\pm 60^{\circ}$ ，垂直方向 $\pm 60^{\circ}$ の範囲につ いて， $5^{\circ}$ ごとに輝度とコントラストを測定した。輝度は，スクリ ーンの中央を $50 \mathrm{~cm}$ の距離から視角 $2^{\circ}$ で測定した。スクリーン中 央には $5 \mathrm{~cm} \times 5 \mathrm{~cm}$ の全画素オンまたはオフのパターンを表示し， 明部と暗部の輝度を別々に測定した。コントラストは, 明部と暗 部の輝度の比をとった。なお，法線方向において輝度とコントラ ストが最大になるように，あらかじめ輝度とコントラストを調整 したうえで測定した。

反射型L C Dについては，スクリーンの法線に対して $45^{\circ}$ 上方 に6Wの白色蛍光灯を配置し, スクリーンの测定対象位置の入射照 度が300 lx になるようにして測定した。自発光型のディスプレイ は, 発光輝度の観視角依存性のみを測定し, 暗部の輝度は, スク リーンの鉛直面照度が300 lx の場合の拡散反射輝度として評価し た。な扮，機種番号3と4の L C Dは，測定しなかった。

\section{4 .2 測定結果}

困 5 は，特定のコントラストを確保できる観視角の範囲を水平 方向と垂直方向について示したものである，L C D 以外の自発光 型のディスプレイは，どのコントラストの基準に対しても，ほと んどが $560^{\circ}$ 以上であったのでここでは，L C Dだけを示した. 従来，LCDのいわゆる視野角は，コントラスト比が2または3以 上確保できる観視角の範囲で表現する場合が多かった。そこで,

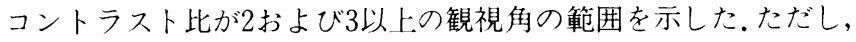

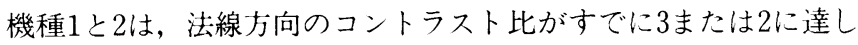
ていなかったので，表示していない部分がある．また，等田7が提 案した視野角の評価基準, すなわち, 法線方向の平方根以上のコ ントラスト比が確保できる観視角の範囲も同様に示した。

水平方向についてみると，機種番号 $5,6,24,25,27 \sim 29$ のアクテ イブマトリックス L C D は, コントラスト比が2以上確保できる観 視角の範囲がすべて $\pm 60^{\circ}$ を越えている。このうち, バックライ
ト型 $(24,25,27$ 29) については，コントラスト比の基準が3にな っても, $\pm 60^{\circ}$ 以上となっている。単純マトリックスのバックライ 卜型 $(7 \sim 23,26)$ は，コントラスト比 2 以上の範囲でみると, $\pm 30^{\circ} \sim \pm 60^{\circ}$ で，機種によってかなり差がある。

垂直方向については，水平方向と比較すると，特定のコントラ ストが確保できる観視角の範囲が概して狭い。また，機種間の差 も比較的大きく，法線方向に対して，上方または下方にずれてい るものが多い. 特に, 機種番号 $24,25,27,28$ のアクィブマトリッ クスは，上方にずれている。これは，ディスプレイの構造上の特 徵によるものと考えられる。

これらの測定結果と, 主観的な視野角の広さとの関係について は，主観評価実験の項で検討する。

\section{3. 表示文字の見やすさに関する主観評価実験}

表示特性を測定した 40 機種のうち22機種について，多次元の評 価項目について主観評価実験を行い，ユーザの視点からディスプ レイが具備すべき物理的条件について検討した。

\section{1 実験方法}

評価対象機種は，表 1 のを付した22機種である。これらは， 主観評価実験を行った時点で奏験室に存在したすべての機種であ る、結果として，ほとんどの方式を網羅できたと考えている。こ れらの機種を，2．の表示特性の測定を行った実験室（図1）に 並べて設置した。実験公の水平面照度は500 600 lx, スクリーン

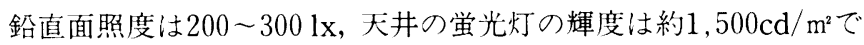
ある、ディスプレイの表示は, 最大輝度, 最大コントラストに調 節した。ただし，C R Tディスプレイは，文字輝度 $75 \mathrm{~cd} / \mathrm{m}^{2}$ ，背景 輝度 $15 \mathrm{~cd} / \mathrm{m}^{2}$ に設定した。スクリーンには日本語の文章を表示し た（15,24,33については日本語が表示できなかったためランダム な英文字またはデモ用の表示とした)，L C D は陽画表示，その他 は陰画表示とし，カラー表示が可能な機種については白色表示に した。

被験者は, 男性 25 名, 女性5名の計 30 名である。いずれも工学部 の学生で, VD T作業の経験を有している. 年羚は21〜26歳, 視 力は0.6〜 1.2 (矯正含む) であった.

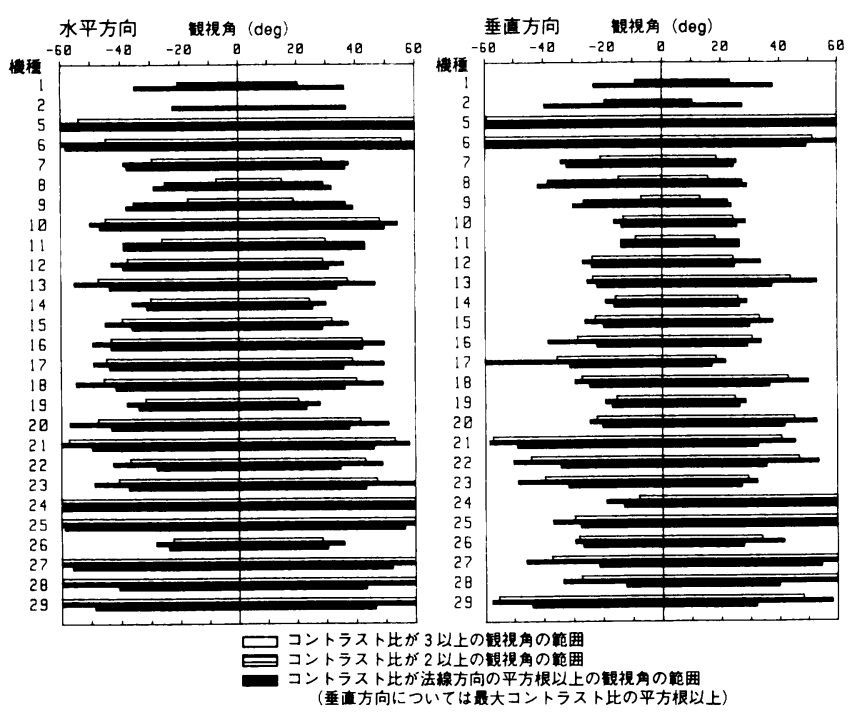

图 5 特定のコントラスト比以上の観視角の範囲 （機種はすべて L C D ： $\pm 60^{\circ}$ を越えるものは $660^{\circ}$ で表した） 


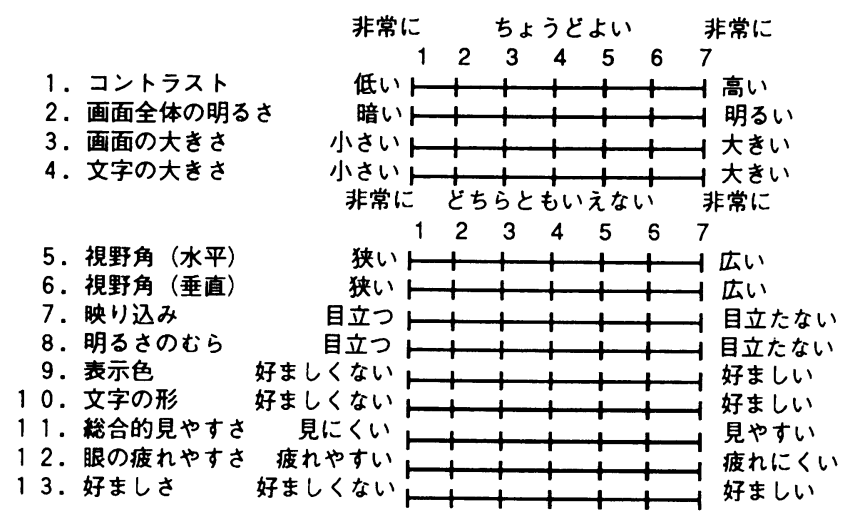

図 6 主観評価実験で用いた評価項目と評価尺度

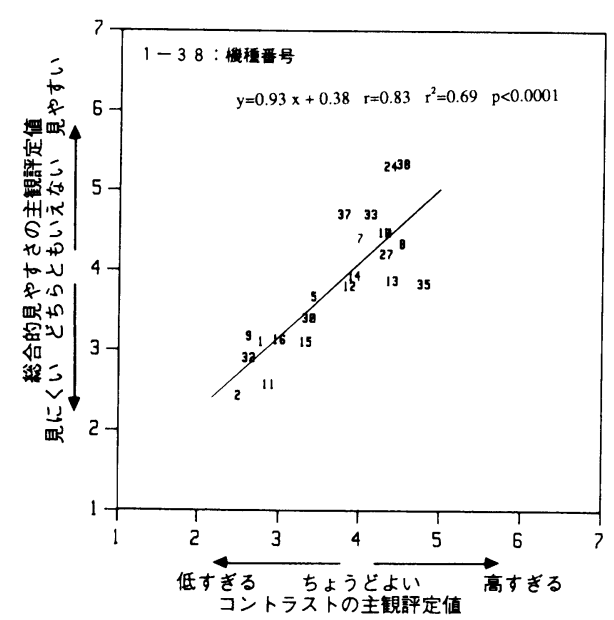

図 7 コントラストの主観評定值と総合的見やすさの主観評定值

評価項目と評価尺度は，図6に示したとおりである。各被験者 は, 機種番号のラベルを付け，機種番号順に並べられている各デ イスプレイを，データシートで指定された順に評価していく。順 序効果を相殺するために, 被験者ごとに異なった順序で各機種を 評価するようにした。また，被験者には評価項目の意味と評価方 法を説明した。たとえば，映り込みについては，天井の蛍光灯を 映り込ませてみること, 視野角については，実際に観視角を変え て見ることなどを教示した。さらに，実際に長時間使用した場合 のことを考慮して評価するように繰り返し指示した。図 6 の13項 目を 22 機種について評価するのに，1被験者あたり約 1 時間を要 した.

\section{2 結果と考察}

\section{2 .1 輝度およびコントラストと見やすさ}

評価項目11の総合的見やすさに，その他の見やすさに関連した 12項目の評定值がどのように影響しているか，その関係を調べる ために重回帰分析を行った。すなわち，30名の被験者の平均評定 值について, 評価項目 $11 の$ 総合的見やすさを目的変量, 残りの 12 項目を説明変量とする重回帰分析(Stepwise Regression)を行っ た。

その結果，互いに相関が高い評価項目が多かったために，図 7 に示したように，総合的見やすさは，評価項目1のコントラストの 評定值でほとんど説明がついてしまうことが明らかとなった。

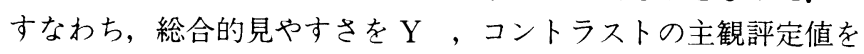

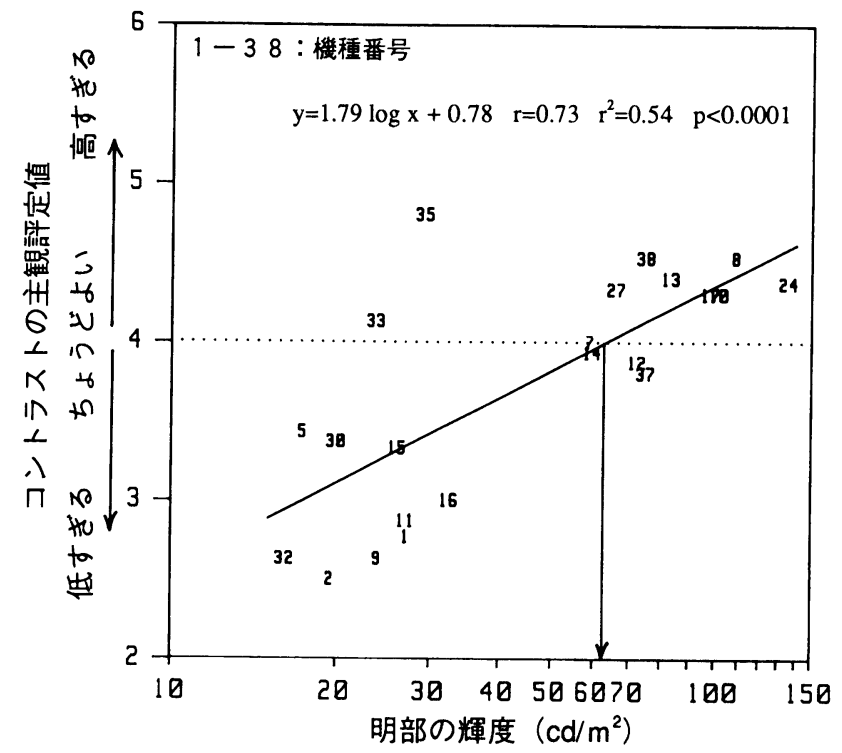

図 8 ディスプレイ明部の輝度とコントラストの主観評定值

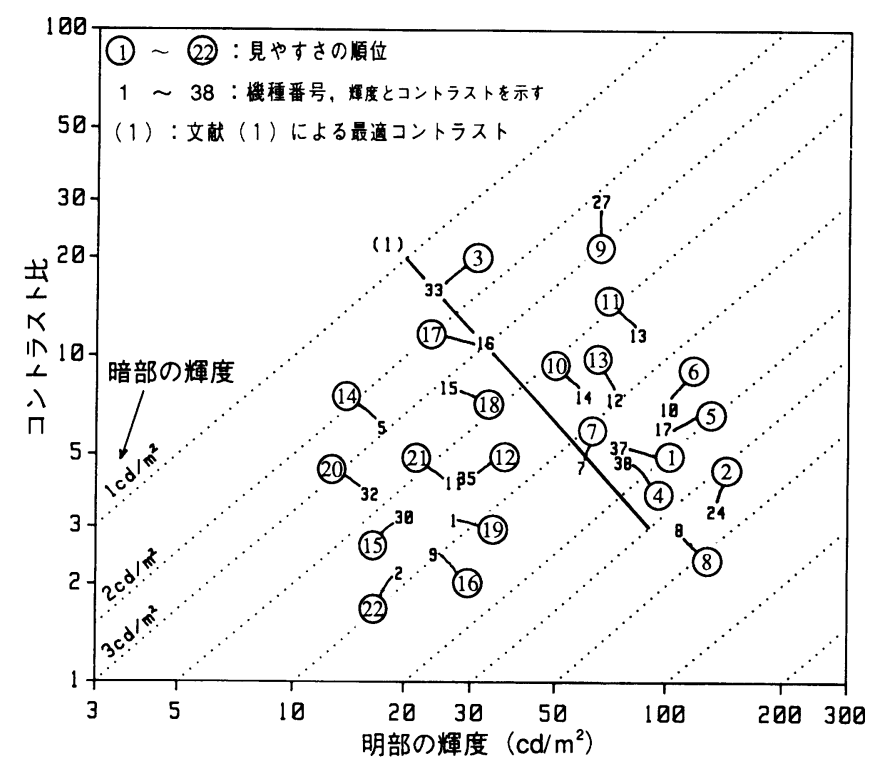

図9ディスプレイの輝度およU゙コントラスト比と総合的な見やすさの関係

$\mathrm{X}$ とすると，

$$
\mathrm{Y}=0.93 \mathrm{X}+0.38
$$

$\left(\mathrm{r}=0.83, \mathrm{r}^{2}=0.69, \mathrm{~F}=44.2, \mathrm{df}=1, \mathrm{p}<0.0001\right)$ という単回帰式で 表すことができる。

そこで, コントラストの主観評定値と表示特性の測定で得られ た物理的なコントラスト值を対応づけてみた。しかし，コントラ ストの主観評定值とコントラスト比の間には有意な相関は認めら れなかった。ところが, 図 8 に示したように, むしろコントラス トの主観評定值は，スクリーンの明部の輝度に依存していること がわかった。すなわち，コントラストの主観評定值を $\mathrm{Y}$ ，スク リーン明部の輝度を X とすると，

$$
\mathrm{Y}=1.79 \log \mathrm{X}+0.78
$$

$\left(\mathrm{r}=0.73, \mathrm{r}^{2}=0.54, \mathrm{~F}=23.3, \mathrm{df}=1, \mathrm{p}<0.0001\right)$ で表すことができ る。この結果から，コントラストの主観評定值 4 の『ちょうどよ い』に対応する輝度は, 約 $60 \mathrm{~cd} / \mathrm{m}^{2}$ となる。 
闵 9 は，評価したディスプレイの輝度およびコントラストと， 評価項目 11 の総合的な見やすさの順位を対応づけた図である。丸 で囲んだ数字は, 総合的見やすさの順位を表し，丸で囲ってない 数字は機種番号であり, 数字の位置は, 明部の輝度とコントラス ト比を示している。

見やすいとされたディスプレイは，比較的高輝度 $\left(50 \sim 60 \mathrm{~cd} / \mathrm{m}^{2}\right.$ 以上）で比較的低コントラスト比 $(3 \sim 6)$ の領域にある。また, すでに述べたように，見や守さに対しては，単なるコントラスト 比よりもスクリーン明部の輝度の方が重要であることがわかる。 たと之ば，機種番号5は，コントラスト比が5以上あるにもかかわ らず，明部の輝度が 10 数 $\mathrm{cd} / \mathrm{m}^{2}$ しかないために, 見やすさの順位 は, 第14位と評価が低い。逆に, 機種番号24は, コントラスト比 が3程度しかないが, 明部の輝度が $100 \mathrm{~cd} / \mathrm{m}^{2}$ 以上あるために, 見や すさの順位は，第2位で評価が高い。

したがって，見やすさの評価を高くするにはスクリーンを明る くする必要があるといえる，LCDについていえば，技術的な鍵 は明るくて均一な輝度が出せるバックライトの開発にあると考之 られる.アクティブマトリックスのT F TのL C Dについては, 開口率を上げパネルの透過率を向上させることも重要だろう．明 部の輝度 $60 \mathrm{~cd} / \mathrm{m}^{2}$ という值はその際のひとつの目安となり得る。 マルチカラーのディスプレイでは，文字表示に緑を使うソフトウ エアが多いので, 緑単独でこの值を達成する必要があ万う.

\section{2 .2 鏡面反射率と映り込みの目立ちにくさ}

スクリーンの鏡面反射率と映り込みの目立ちにくさの関係を調 べたところ, $1^{\circ}$ の光源に対する鏡面反射率の対数值と映り込みの 目立ちにくさの主観評定值の相関が最も高かった $\left(\mathrm{r}=0.79, \mathrm{r}^{2}=\right.$ $0.62, \mathrm{~F}=32.4, \mathrm{p}<0.0001)$. その結果は, 図10に示したとおりであ る。その他の大きさの光源に対方る鏡面反射率の対数值と映り込 みの目立ちにくさの相関も有意であったが，光源が大きくなるほ ど寄与率が低下した。これは, 主観評価実験で映り込ませた天井 照明の大きさが視角 $1^{\circ}$ 以下であったためである。

困10の結果を機種ごとに検討してみると，鏡面反射率だけでな

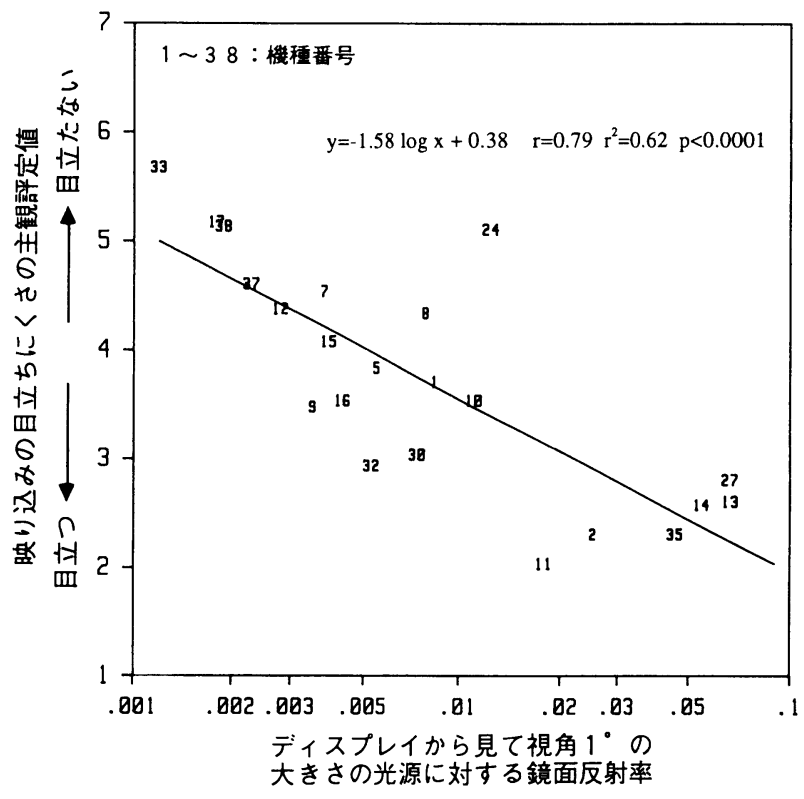

図10 ディスプレイから見て視角 1 。の大きの光源に対する 鏡面反射率と映り込みの目立ちにくさの関係

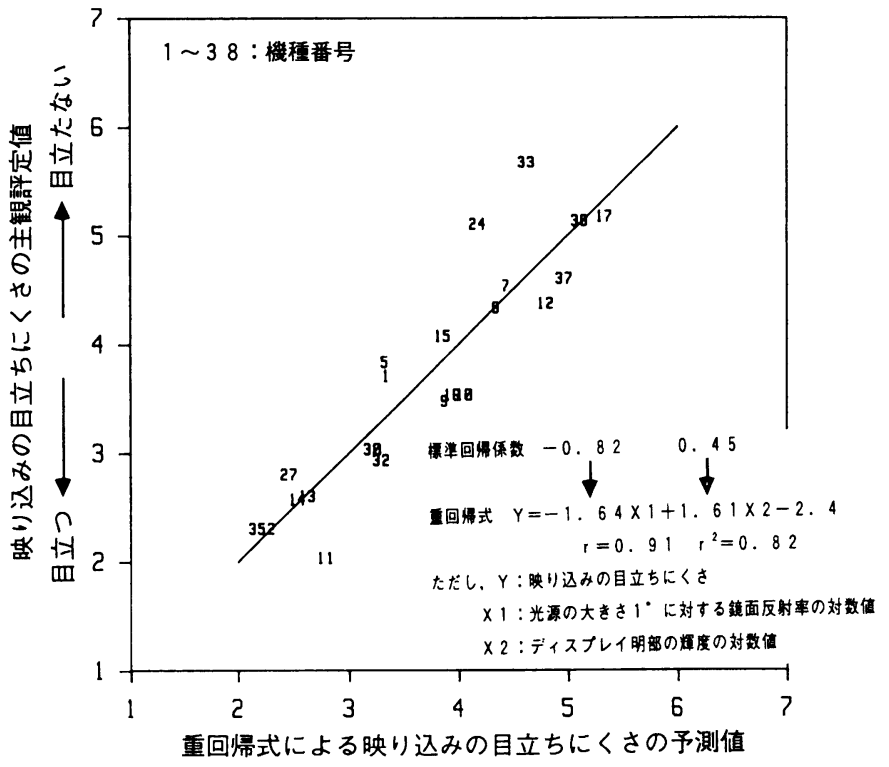

図11鏡面反射率と表示輝度を変数にした映り込みの目立ちにくさ の予測值と映り込みの目立ちにくさの主観評定值の関係

く, ディスプレイの表示輝度が, 映り込みの主観評定值に影響し ていることがわかる、すなわち，鏡面反射率が同程度でも，表示 輝度が高い方が映り込みの目立ちにくさの評価が高い.

そこで, 映り込みの目立ちにくさを目的変量, 光源の大きさ $1^{\circ}$ に対する鏡面反射率の対数值と，ディスプレイの明部の輝度の対 数值を説明変量にした重回帰分析を行った。結果は, 式(4)拉よび 困11に示したとおりである。

$$
\mathrm{Y}=-1.64 \mathrm{X} 1+1.61 \mathrm{X} 2-2.4
$$

$\left(r=0.91, r^{2}=0.82, \quad F=43.98, \quad d f=2, \quad p<0.0001\right)$

ただし， $\mathrm{Y}$ ：映り込みの目立ちにくさ

$\mathrm{X} 1$ : 光源の大きさ $1^{\circ}$ に対する鏡面反射率の常用対数值

$\mathrm{X} 2$ ：ディスプレイの明部の輝度 $\left(\mathrm{cd} / \mathrm{m}^{2}\right)$ の常用対数值 X1とX2の標準回帰係数は，それぞれー0.82と0.45であった.した がって，ディスプレイの表示輝度の要因も映り込みの目立ちにく さにかなり影響していることがわかる。

ここで, 等田, 高橋5の反射の許容輝度を求めた実験結果をこの 式(4)に代入して, 映り込みの目立ちにくさの許容值を求めてみ た。本実験で評価したディスプレイのほとんどが陽画表示であっ たので, 洼田, 高橋の陽画表示における反射の許容輝度を代入し た。すなわち, 陽画表示で明部の輝度が $60 \mathrm{~cd} / \mathrm{m}^{2} の$ 場合, 鏡面反射 輝度の許容值は, $16 \mathrm{~cd} / \mathrm{m}^{2}$ であった。鏡面反射輝度 $16 \mathrm{~cd} / \mathrm{m}^{2}$ は, 光 源の輝度が $1,500 \mathrm{~cd} / \mathrm{m}^{2}$ であるから，鏡面反射率では 0.0107 とな る、鏡面反射率 0.0107 と明部の輝度 $60 \mathrm{~cd} / \mathrm{m}^{2}$ を式 (4)に代入する と，予測値は $3.70 に な る 。 す な わ ち ， 1,500 \mathrm{~cd} / \mathrm{m}^{2}$ の天井照明の映 り込みを想定した場合，式 (4)の値が 3.70 以上になるように, 鏡面 反射率と表示輝度を設定すれば，映り込みがほぼ許容できること になる。

そこで, 式(4)の $\mathrm{Y}$ を 3.70 とすると, $1,500 \mathrm{~cd} / \mathrm{m}^{2}$ の照明器具の映 り込みが許容できる鏡面反射率と表示輝度の限界值の関係は, 次 のように表すことができる。すなわち，

$\log \mathrm{S} \mathrm{r}=(1.61 \log \mathrm{L} \mathrm{h}-6.10) / 1.64$

ただし， $\mathrm{S} \mathrm{r}$ : 鏡面反射率, $\mathrm{L} \mathrm{h}$ : 明部の輝度 $\left(\mathrm{cd} / \mathrm{m}^{2}\right)$ である. また，鏡面反射率二鏡面反射輝度／光源の輝度であるから，映り 
表2 ディスプレイに映り込んだ照明器具の反射映像の輝度を 許容值以下にするための照明器具の輝度, ディスプレイ の表示輝度，鏡面反射率の関係。ただし，ディスプレイ の表示極性は陽画表示で,ディスプレイから見た光源の 大きさは視角 $1^{\circ}$ 以下の場合；表中の数值はディスプレ イから見て視角 1 の大きさの光源に対字るディスプレ イの鏡面反射率を示吉.

\begin{tabular}{r|rrrr}
\hline $\begin{array}{r}\text { 表示楎度 } \\
\left(\mathrm{cd} / \mathrm{m}^{2}\right)\end{array}$ & 50 & \multicolumn{4}{|c}{ 照明器具の輝度 $\left(\mathrm{cd} / \mathrm{m}^{2}\right)$} \\
\hline 10 & .0549 & .0137 & .0014 & .0003 \\
20 & .1084 & .0271 & .0027 & .0007 \\
30 & .1613 & .0403 & .0040 & .0010 \\
40 & .2140 & .0535 & .0053 & .0013 \\
50 & .2664 & .0666 & .0067 & .0017 \\
60 & .3186 & .0796 & .0080 & .0020 \\
70 & .3706 & .0927 & .0093 & .0023 \\
80 & .4226 & .1056 & .0106 & .0026 \\
90 & .4744 & .1186 & .0119 & .0030 \\
100 & .5260 & .1315 & .0132 & .0033 \\
110 & .5776 & .1444 & .0144 & .0036 \\
120 & .6292 & .1573 & .0157 & .0039 \\
130 & .6806 & .1701 & .0170 & .0043 \\
140 & .7319 & .1830 & .0183 & .0046 \\
150 & .7832 & .1958 & .0196 & .0049 \\
\hline
\end{tabular}

込んでいる光源の輝度を L o とすると, 式(5)から,

$\log (1500 \cdot \mathrm{S} \mathrm{r} / \mathrm{L} \mathrm{o})=(1.61 \log \mathrm{L} \mathrm{h}-6.10) / 1.64$ (6) となり, 映り込みの許容限界に打ける, 照明器具の輝度, 表示輝 度, 鏡面反射率の関係が求められる。

表 2 に，これらの関係を示した。ただし，ディスプレイの表示 極性は陽画表示で，映り込み対象物は，天井の照明器具のような ディスプレイからみた視角 1 ○以下のものという前提である。面 積が大きな対象物, たとえば，作業者の白いシャツなどの映り込 みについては，この式は成り立たない。ただし，面積が大きな対 象物の輝度は概して低いので, 鏡面反射率が余程高くない限りあ まり問題にはならないだろう。照明器具の輝度は, 照明学会8)が提 示したV D Tを使用するオフィスの照明器具の輝度制限值 V 1 〜V 3 (それぞれ $\left.50,200,2,000 \mathrm{~cd} / \mathrm{m}^{2}\right)$ と, 蛍光灯の平均的な輝 度として $8,000 \mathrm{~cd} / \mathrm{m}^{2}$ 適用した。

この表から, たとえば, 照明器具の輝度が $200 \mathrm{~cd} / \mathrm{m}^{2} の$ 場合, 表 示輝度が $40 \sim 60 \mathrm{~cd} / \mathrm{m}^{2}$ のディスプレイでは, 鏡面反射率は 0.05〜0.08まで許容できることを示す.鏡面反射率 $0.05 〜 0.08$ ， ポリッシュのCRTディスプレイの鏡面反射率に相当する。従来, $\mathrm{DIN}^{9)}, \mathrm{CIE}^{10)}$, 照明学会 ${ }^{11), 12)}$, 日本電子工業振興協会 2 などの多く が, VDT作業場の照明器具の輝度は, 鉛直角 $50 \sim 60^{\circ}$ 以上で 200 $\mathrm{cd} / \mathrm{m}^{2}$ 以下が望ましいとしているが，これはポリッシュのC R T を対象にしたものであることがこの結果からも理解できる。

最近になって, 照明学会8)が提示した $2,000 \mathrm{~cd} / \mathrm{m}^{2}$ という照明器 具の輝度制限值を適用すると, ディスプレイの表示輝度が $60 \mathrm{~cd} /$ $\mathrm{m}^{2}$ の場合, 鏡面反射率は, 0.008 が許容限界值である。この值は, C R Tでは拡散処理で達成できる。しかし，本研究で測定した29
機種の L C Dのうち，この値を達成できているのは半数以下の 13 機種である。

また，輝度制御をしていない一般的な蛍光灯の輝度が $8,000 \mathrm{~cd} /$ $\mathrm{m}^{2}$ とすると,ディスプレイの表示輝度が $60 \mathrm{~cd} / \mathrm{m}^{2}$ では, 鏡面反射率 を0.002まで下げる必要がある。この值は，良質のマルチコーティ ングを施したC R T, もしくは極端な拡散処理を施したディスプ レイでしか達成できない值である。しかし，輝度制御をしていな いオフィスで使われているVDTの方が多い4ことからすると, ディスプレイの鏡面反射率は, このレベルまで下げる必要があろ j.本研究で測定した40機種のディスプレイの中では, L C D 2 機 種を含む4機種がこの值を達成できている.

\subsection{3 コントラストの観視角依存性と視野角の広さ}

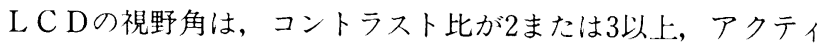
ブマトリックスでは10以上確保できる観視角の範囲と定義する場 合が多い。この視野角の定義は，ユーザの視覚系に対応したもの ではなく、ディスプレイの物理的な性能を示すために便宜的に決 められたものである。筆者は，主観的に表示文字の読み取り作業 に差し支えない観視角の範囲を視野角と定義した。

図12は，視野角の広さの主観評価結果で，水平方向と垂直方向 の視野角の評価結果を表したものである。ほぼ $45^{\circ}$ の直線上にデ 一夕が分布している。つまり，水平方向の視野角が狭く感じられ ているディスプレイは，垂直方向も狭く感じられていることを示 す。また，単純マトリックスの L C D 群と，アクティブマトリッ クスの L C D および自発光型ディスプレイ群に二分されることが わかる.したがって，バックライト型のアクティブマトリックス L C D は自発光型のディスプレイと視野角の面で主観的には遜色 がないといえる。

L C D の視野角を主観評価実験により求めた研究7によると, 法線方向のコントラスト比と文字の読み取り作業に差し支之ない 許容限界の観視角におけるコントラスト比との間には，对数値で 約 $2: 1 の$ 関係があることが明らかとなっている.すなわち, 法線方 向のコントラスト比の平方根以上のコントラスト比が確保できる 観視角の範囲を視野角とすると, ユーザの視覚系との対応がよく, 現実的であるとしている。

そこで, 水平方向の視野角の主観評定結果と, 2.4 節で求めたコ ントラスト比が法線方向の平方根となる観視角との对応を調べ た。

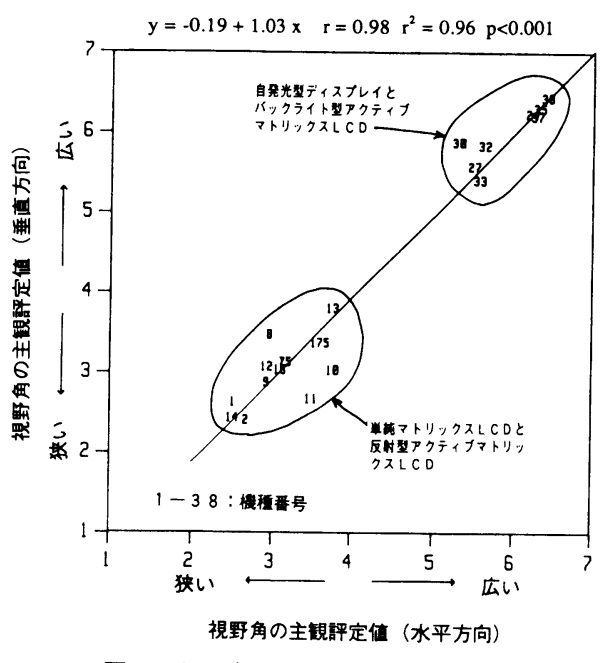

図12 視野角の広さの主観評定結果 


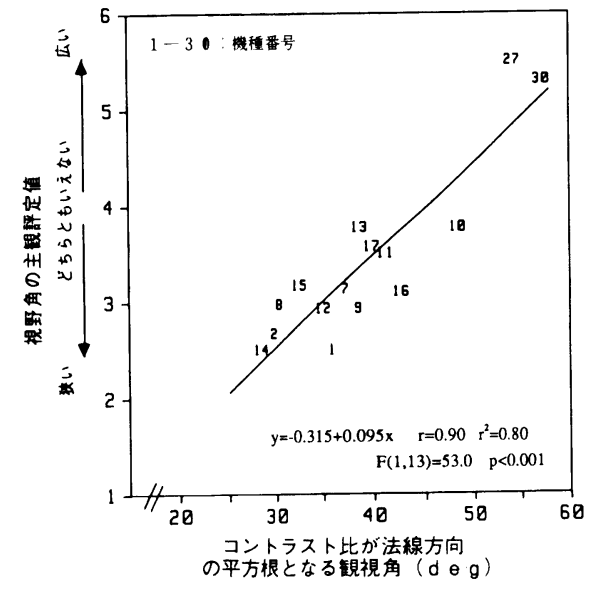

図13 コントラスト比が法線方向の平方根となる観視角と 視野角の主観評定値の関係

その結果, 視野角の主観評定值と, コントラスト比が法線方向の 平方根となる観視角（左右の平均値）との間には，図13に示した ように，きわめて高い相関関係が認められた $\left(\mathrm{r}=0.90, \mathrm{r}^{2}=80, \mathrm{~F}\right.$ $(1,13)=53.0, \mathrm{p}<0.001)$.

以上の結果は, 法線方向のコントラスト比の平方根以上のコン トラスト比が確保できる観視角の範囲を測定すれば，L C Dの視 野角の広さを評価できることを意味している，ただし，実作業に おいて視野角をどこまで確保すればよいかについては，作業の特 性も考虑にいれた広い視点からの検討を要寸る。現状では，でき る限り視野角を広げることが, より広範囲のユーザに受け入れら れるための条件であると考之る。

今後, 視覚パフォーマンスの側面から, 有効な観視角の範囲を 測定することが必要となろう。また，階調表示や多色表示に対寸 る視野角の規定の仕方についても検討しなくてはならない。

\section{4.まとめ}

本研究では，L C Dを中心とする各種 F P D を対象として，ど のような表示特性を具備すれば, 実際のオフィスの照明環境下で, ユーザにとって見やすい表示が得られるかについて奉験的に検討 した。測定・評価した表示特性は，輝度およびコントラスト，鏡 面反射率，コントラストの観視角依存性である。

主な結果は，以下のようにまとめられる。

(1）F P Dの主観的な見やすさは，コントラスト比よりも，主に スクリーンの明部の輝度に依存しており，平均的なオフィスの 光環境条件下では, 約 $60 \mathrm{~cd} / \mathrm{m}^{2}$ が好まれる.

（2）照明器具の映り込みの目立ちにくさは，視角 $1^{\circ}$ の大きさの
光源に対するディスプレイの鏡面反射率と明部の輝度によって 子測できる。この子測式に，鏡面反射の許容輝度值を求めた従 来の研究結果を対応づけると, 輝度 $8,000 \mathrm{~cd} / \mathrm{m}^{2}$ の営光灯照明に 対しては, 明部の輝度が $60 \mathrm{~cd} / \mathrm{m}^{2}$ の陽画表示のディスプレイで は，鏡面反射率を 0.002 程度まで下げる必要がある。

（3）主観的な視野角の広さは，コントラスト比が法線方向の平方 根以上確保できる観視角の広さと対応している。すなわち，コ ントラスト比が法線方向の平方根以上となる観視角の範囲が広 いディスプレイほど,ユーザから見て視野角が広く感じられる. 今後, 主観評価実験だけでなく, 視作業のパフォーマンスを指 標にした実駼を行い, 視認性が高く視覚負担の少ないディスプレ イの物理的条件について，娭討していく予定である.

最後に，本研究に対して便宜を図っていただきました日本電子 工業振興協会VDT動向調査専門委員会の関係者各位に対し厚く お礼申し上げます。

参考文 献

(1) 法田 悟：C R Tディスプレイの人間工学的設計指針の検 討，人間工学，26-6，(1990)，337-344

(2) 日本電子工業振興協会：VDTがイドラインに関する調査 研究報告書, 60-A-233, (1985)

（3）日本規格協会：業務用陰極線管及U゙けん盤，JIS X-6041, (1987)

（4）高橋 誠, 窪田 悟, 西岡 昭：VDT作業場の光環境に 関寸る実態調查，労働科学，63-4，(1987)，181-191

（5）洼田 悟, 高橋 誠：C R Tディスプレイ上の光源の反射 像の許容輝度, 照明学会誌, 73-6, (1989), 314-318

（6）労働省：V D T 作業のための労働衛生上の指針, 中央労働 災害防止協会，（1985）

（7）洼田 悟：液晶ディスプレイの視野角の評価, テレビジョ ン学会誌, 46-3, (1992), 354-356

（8）照明学会：オフィス照明新基準，オフィス照明新基準作成 委員会報告書, (1991)

(9) DIN : DIN 5035 Teil 7, (1986)

(10) CIE : Vision and the Visual Display Unit Work Station, CIE Publication No.60, (1984)

(11) 照明学会：VDT表面における照明の反射グレア・光幕反 射の防止, 新時代の照明環境研究調査委員会報告, 照明学 会技術指針 No.JIEG-005，（1986）

(12) 照明学会：人間・機械系に扔ける照明環境研究報告書, 人 間・機械系における照明環境研究調査委員会報告, 照明学 会報告書 No.JIER-007，（1986） 